\title{
Stainless steel and NiTi torque archwires and apical root resorption
}

\author{
Andrea Wichelhaus ${ }^{1} \cdot$ Marc Dulla $^{1} \cdot$ Hisham Sabbagh ${ }^{1} \cdot$ Uwe Baumert $^{1} \cdot$ Thomas Stocker $^{1}$ \\ Received: 17 December 2018 / Accepted: 24 April 2020 / Published online: 1 September 2020 \\ (c) The Author(s) 2020
}

\begin{abstract}
Objective The amount of apical root resorption when using the torque-segmented archwire (TSA) was investigated as well as the extent and direction of the therapeutically indicated apical movement and the treatment duration.

Materials and methods The degree of apical root resorption in 18 randomly chosen Class II and Class I patients treated with the TSA, as well as in 18 conventionally treated patients were evaluated using pre- and posttreatment panoramic radiographs. The sagittal and vertical apical movements and inclination changes were determined based on pre- and posttreatment lateral cephalograms. Nonparametric tests were applied to test between treatment groups and steps. The Mann-Whitney U test, Kruskal-Wallis, Pearson correlation and Wilcoxon signed-rank test were applied for statistical analysis $(p<0.05)$.

Results The incidence of root resorptions was $89-94.4 \%$ in low or moderate level. The relative root-crown ratio (rRCR) was not statistically different between the TSA and control groups except tooth 12 . The axis of the incisors in the TSA group was significantly improved. The main direction of movement of the apices of the central incisors was retrusion and extrusion. No interdependence between the amount of resorption and the parameters of treatment duration, extent and direction of apical movement were found.

Conclusion The results of the study showed that the amount of apical root resorption with the TSA is slight to moderate and can be compared to conventional orthodontic treatment. The TSA is hence a suitable method for applying targeted torques to the incisors.
\end{abstract}

Keywords Incisors · Orthodontic therapy $\cdot$ Tooth movement $\cdot$ Root-crown ratio $\cdot$ Orthodontic appliances

\section{Edelstahl- und NiTi-Torquesegmentbogen und apikale Wurzelresorption}

\section{Zusammenfassung}

Ziel Der Umfang der apikalen Wurzelresorption ebenso wie das Ausmaß und die Richtung der therapeutisch angenommenen apikalen Bewegung sowie die Behandlungsdauer wurden bei Anwendung des Torquesegmentbogens (TSB) untersucht. Methoden Das Ausmaß der apikalen Wurzelresorption wurde an 18 willkürlich ausgewählten Klasse-II- und -I-Patienten, die mit dem TSB behandelt wurden, und an 18 konventionell behandelten Patienten anhand von prä- und posttherapeutisch erstellten Panoramaschichtaufnahmen beurteilt. Die sagittalen und vertikalen apikalen Bewegungen sowie die Änderungen der Inklination wurden anhand der FRS(Fernröntgenseitenbilder)-Aufnahmen bestimmt. Unterschiede zwischen Behandlungsgruppen und -schritten wurden mit nichtparametrischen Tests bestimmt. Mann-Whitney-U-, Kruskal-Wallis-, Pearson-Korrelation- und Wilcoxon-Rangsummen-Tests wurden zur statischen Analyse verwendet $(p<0.05)$.

Prof. Dr. Andrea Wichelhaus

kfo.sekretariat@med.uni-muenchen.de

1 Department of Orthodontics and Dentofacial

Orthopedics, University Hospital, LMU Munich,

Goethestraße 70, 80336 Munich, Germany 
Ergebnisse Die Inzidenz der Wurzelresorption betrug 89-94,4\% für geringes bis moderates Ausmaß. Es gab keinen statistisch signifikanten $\mathrm{RCR}$ (,,relative root-crown ratio“)-Unterschied zwischen der TSB- und der Kontrollgruppe bis auf Zahn 12. Die Inzisivusachse in der TSB-Gruppe wurde signifikant verbessert. Die Hauptbewegungsrichtung der Apices der zentralen Schneidezähne waren Retrusion und Extrusion. Es fand sich keine Interdependenz zwischen dem Umfang der Resorption und den Parametern Behandlungsdauer, Ausmaß und Richtung der apikalen Bewegung.

Schlussfolgerung Die Studienergebnisse zeigen, dass der Umfang der apikalen Wurzelresorption mit TSB leicht bis moderat ist und mit der konventionellen orthodontischen Behandlung vergleichbar. Der TSB ist daher geeignet, Torque auf die Schneidezähne zu übertragen.

Schlüsselwörter Frontzähne · Kieferorthopädische Therapie $\cdot$ Zahnbewegung · Wurzel-Kronen-Verhältnis ·

Orthodontische Apparaturen

\section{Introduction}

The root torque of the anterior teeth is an important tool in orthodontic treatment. The buccopalatal angulation of the root known as palatal root torque in orthodontics is an important step in creating functionally correct static and dynamic occlusal relationships and guaranteeing good support to the anterior teeth. Bodily retraction of the anterior teeth and simultaneous application of torque are often necessary, especially in the course of premolar extraction treatment.

For correct axial adjustment of the roots of the incisors, torque must be transferred to the teeth via orthodontic appliances. The torque angle in the bracket when using the straight wire technique does not transfer suitable torques in many cases because of slot geometry [53]. In these cases, a defined, biomechanically effective torque therefore needs to be produced via torsion of wires. The torques dependent on applied force and range between 15 and $20 \mathrm{Nmm}$ as recommended in the literature [5] for all four upper incisors [55]. However, in some instances torques of around $5 \mathrm{Nmm}$ are also specified [39]. These values ascertained from the literature are a guide and are dependent on the root geometry of the teeth or the biological circumstances in the individual patient. If forces and torques are biomechanically uncontrolled or too high, the risk of apical root resorptions will increase [10, 13, 34, 45]. In addition to the force and torque magnitude, the duration of force/torque application, force direction, treatment mechanics and treatment period should be noted as influencing variables in relation to resorption [2, 17, 23, 28, 31, 33, 34]. Torque movement of the apex causes a local concentration of pressure at the root tip and can reach a fourfold level compared with pure translatory tooth movements [47]. However, root apex resorptions are dependent on genetic and biological factors as well as the effects of the orthodontic treatment [51].

Nickel-titanium alloys (NiTi) are particularly well suited to transfer small forces and torques to the teeth because of their low Young's modulus [6, 54]. In addition, the alloy is characterized by its superelastic material behavior. However, this behavior only arises when the material is adequately stretched or loaded. As a result, defined forces and torques can be orthodontically applied as well as small forces and torques. To utilize the superelasticity of NiTi alloy in order to change incisors' root torque a segment of a stainless steel archwire was replaced with NiTi alloy. This combination provides the rigidness and stability of stainless steel on the "side-parts" on the one hand, as well as the small forces and torques produced by the superelastic $\mathrm{NiTi}$ alloy on the other hand. Torque segmented archwires (TSA), which were developed specifically for this purpose $[47,55]$, are available in prefabricated form (Forestadent, Pforzheim, Germany). The TSA consists of a pretorqued superelastic archwire component (NiTi) for the incisors and two steel segments attached via a clamp connection for the posterior teeth (Fig. 1a). If the mechanical load-deflection behavior of the entire TSA compound is measured as published by Wichelhaus and Sander [55], the resulting curve shows an incomplete superelasticity even though the frontal segment is made from superelastic material. This can be attributed to the fact that it is not possible to separate the NiTi hysteretic behavior from the linear elasticity of the stainless steel component. However, it has to be considered that the mechanical performance of the entire TSA compound is clinically almost irrelevant because the main stresses and moments are generated in the interbracket segments which are made of either stainless steel or NiTi. To prove the superelastic character of the TSA's NiTi part, three-point bending measurements were conducted (Fig. 1b).

As apical root resorptions are a very commonly occurrence with the upper incisors $[2,46]$, the aim of the present study in using the TSA was to investigate the amount of apical root resorption compared with conventional orthodontic appliances. Furthermore, the extent and direction of the therapeutically indicated apical movement and the treatment duration were also evaluated. 


\section{Materials and methods}

\section{Patient groups}

In a randomized retrospective follow-up study, we investigated the effect of TSA versus conventional orthodontic appliance application on the amount of apical root resorption. As such, the study group comprised of 18 randomly chosen successfully treated Class I and Class II patients (11 female, 7 male) from the Department of Orthodontics and Pediatric Medicine of Basel University and included 7 extraction cases. The complementary control group consisted of 18 randomly chosen Class I and Class II patients (11 female, 7 male) from the Department of Orthodontics and Dentofacial Orthopedics of the University of Munich and included 10 extraction cases. In all cases, there was a therapeutic necessity to apply torque on the maxillary incisors. In our treatment concept, torque with the stainless steel wire is not applied in patients with critical anchorage. In this case, we prefer the TSA because the sagittal force is lower in comparison to the stainless steel arch wire. Both methods apply torque changes to the maxillary incisors. The local ethics committee approved the study protocol (project number 19-815). On average, torque treatment of the patients in the study group started at $18.6 \pm 7.5$ years of age (range 11.4-37.3 years) and lasted for $105 \pm 44$ days. Within the control group patient torque treatment started at $14.8 \pm 1.8$ years of age (range 12.6-18.9 years). These patients were treated for $146 \pm 52$ days.

The torque application by means of the TSA took place using a standardized archwire sequence: $0.014^{\prime \prime} \mathrm{NiTi}$, $0.016^{\prime \prime} \mathrm{NiTi}, 0.016^{\prime \prime} \times 0.022^{\prime \prime} \mathrm{NiTi}, 0.016^{\prime \prime} \times 0.022^{\prime \prime}$ stainless steel, TSA $\left(0.018^{\prime \prime} \times 0.025^{\prime \prime} \mathrm{NiTi}\right.$ with $45^{\circ}$ pretorque $)$ and $0.018^{\prime \prime} \times 0.025^{\prime}$ stainless steel in the $0.022^{\prime \prime}$ slot technique with MBT prescription. The effective torque in the $0.018^{\prime \prime} \times 0.025^{\prime \prime}$ wire dimension is about $2^{\circ}$ [11]. If sweep is necessary, an additional torque of $15^{\circ}$ occurs. If no sweep is necessary, a torque of $30^{\circ}$ was bent into the wire applying a moment of $20 \mathrm{Nmm}$ [8].

The tooth axis in relation to the occlusal plane was clinically controlled with a special torque key [55]. The archwire sequence applied in the control group was identical to the one previously described, but without TSA.

Hier steht eine Anzeige.

Springer 


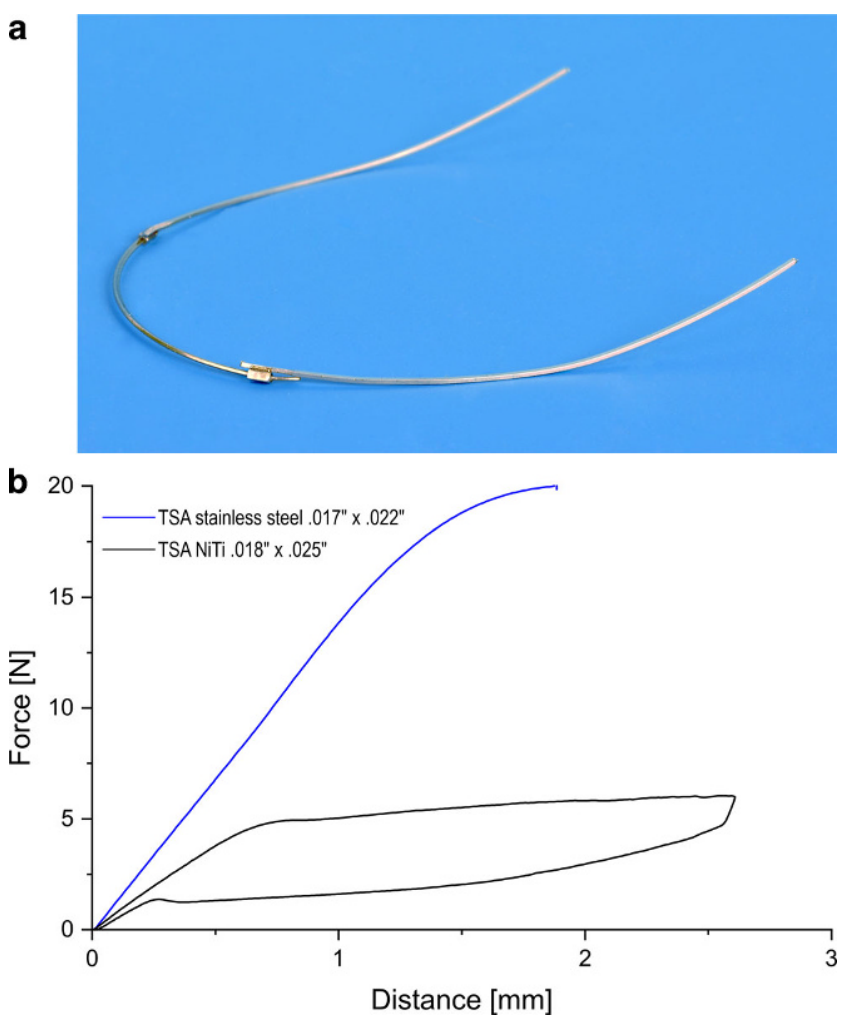

Fig. 1 a Torque segmented archwire (TSA) with 1st (horizontal contouring), 2nd (sweep) and 3rd order bends (buccal root torque). b Mechanical characteristics of the individual parts of an TSA. Stainless steel shows Hookean behavior, whereas the NiTi alloy part exhibits the typical hysteresis curve

Abb. 1 a Torquesegmentbogen (TSA) mit Biegungen 1. (horizontale Konturierung), 2. (Sweep) und 3. Ordnung (bukkaler Wurzeltorque). b Mechanische Eigenschaften der individuellen Bestandteile eines TSA. Der Edelstahlbogen zeigt Hooksches Verhalten, während die NiTi-Komponente eine typische Hysteresekurve erzeugt

\section{Examination of radiographs}

For all patients lateral cephalograms and panoramic radiographs taken before and after treatment were examined. Because of the retrospective character of the study, no specific fixation devices were used for $\mathrm{X}$-rays, and the $\mathrm{X}$-rays taken routinely for diagnostics were used for the evaluation in this study.

For each of the examined panoramic radiographs root and crown length of the central and lateral incisors were measured according to the method presented by Linge and Linge [27] and Fritz et al. [15]. The distance between the incisal edge and the cementoenamel junction represented the crown length, correspondingly the distance between the cementoenamel junction and the apex represented the root length (Fig. 2). Because the crown length should not change during treatment, the proportion between crown and root length should stay constant in different radiographs of the same teeth at the same time. This allows to rate the radiographs widely independently of projections, recording angles or nonstandardized conditions [15, 26]. Using these measures, the root-to-crown-ratio (RCR) before and after treatment for each of the examined teeth was calculated (Fig. 2). The relative root-to-crown ratio (rRCR) (Fig. 2, formula) is the quotient of the RCR values of a given tooth before and after treatment and, thus, reflects the amount of root resorption $[15,16,26]$. As such, a $\mathrm{rRCR} \geq 100 \%$ means "no resorption" and rRCR values $<100 \%$ signify root resorption.

The torque change resulting from treatment as well as the apical movement achieved were assessed by comparing the pre- and posttreatment lateral cephalograms. The two X-rays were overlaid so that the anatomical structures corresponded as closely as possible. In order to assess the degree of displacement of the upper central incisors, two different measurements were acquired: (1) assessment of the sagittal and horizontal apical movement (Fig. 3) and (2) the torque change to the upper central incisors that was achieved (Fig. 4).

\section{Statistics}

Descriptive and inferential statistics were calculated using IBM SPSS Statistics 25 (IBM Corp., Armonk, NY, USA). Cephalometric measurements and relative root-to-crown ratios were presented with mean, standard deviation (SD), range (minimum to maximum), median, and interquartile range. Since most of the measurements showed deviation from the assumption of normality and due to the sample size nonparametric inferential methods were applied. Differences between the patient groups were assessed by the Mann-Whitney U test, whereas difference between pre- and posttreatment were examined using the Wilcoxon signedrank test. Kruskal-Wallis testing was applied to test for differences in rRCR between the different teeth in each group

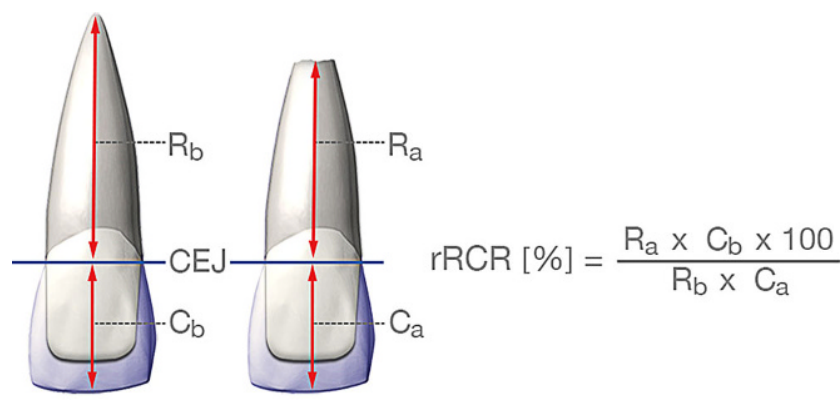

Fig. 2 Assessment of pre- and posttreatment crown $\left(\mathrm{C}_{\mathrm{X}}\right)$ and root $\left(\mathrm{R}_{\mathrm{x}}\right)$ length (CEJ cementoenamel junction) according to Fritz et al. [15]. Individual relative root-crown ratios (rRCR) were calculated using preand posttreatment root and crown length using the given equation Abb. 2 Bestimmung der Kronen- und Wurzellängen $\left(C_{x}\right.$ und $\left.R_{x}\right)$ präund posttherapeutisch (CEJ Schmelz-Zement-Grenze) nach Fritz et al. [15]. Die Berechnung der individuellen relativen Wurzellängenänderung (rRCR) erfolgte gemäß der dargestellten Formel 


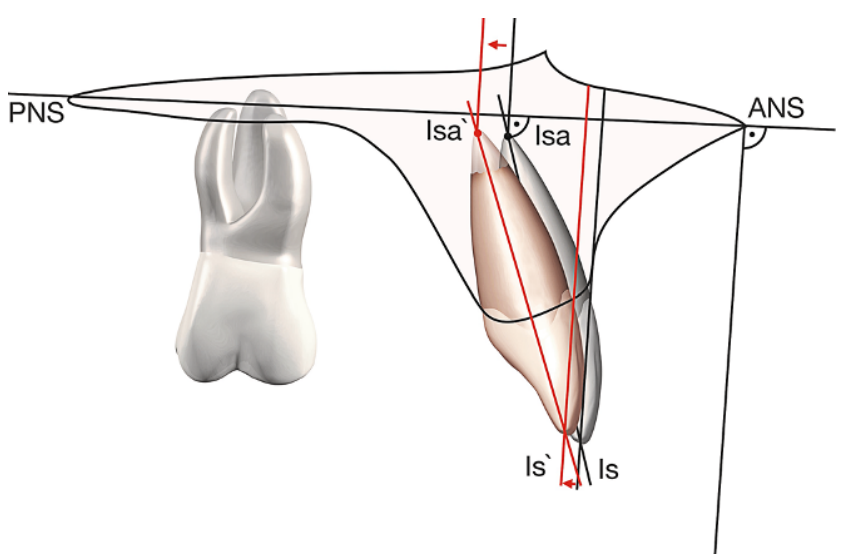

Fig. 3 Analysis of the amount of movement of the apex based on preand posttreatment lateral cephalograms. Sagittal and vertical movements $(\mathrm{mm})$ were determined. ANS anterior nasal spine, PNS posterior nasal spine, Is $a$ incision superius apicalis, Is incision superius

Abb. 3 Analyse des Bewegungsausmaßes des Apex anhand prä- und posttherapeutischer Fernröntgenseitenbilder. Es wurden sagittale und vertikale Bewegungen bestimmt (mm). ANS ,,anterior nasal spine“, $P N S$,,posterior nasal spine”, Isa ,incision superius apicalis”, Is ,,incision superius"

separately. The Pearson correlation was applied to test the relationship between root resorption and apical movements and between torque changes of the maxillary incisors and root resorption. The level of significance was set at $p<0.05$.

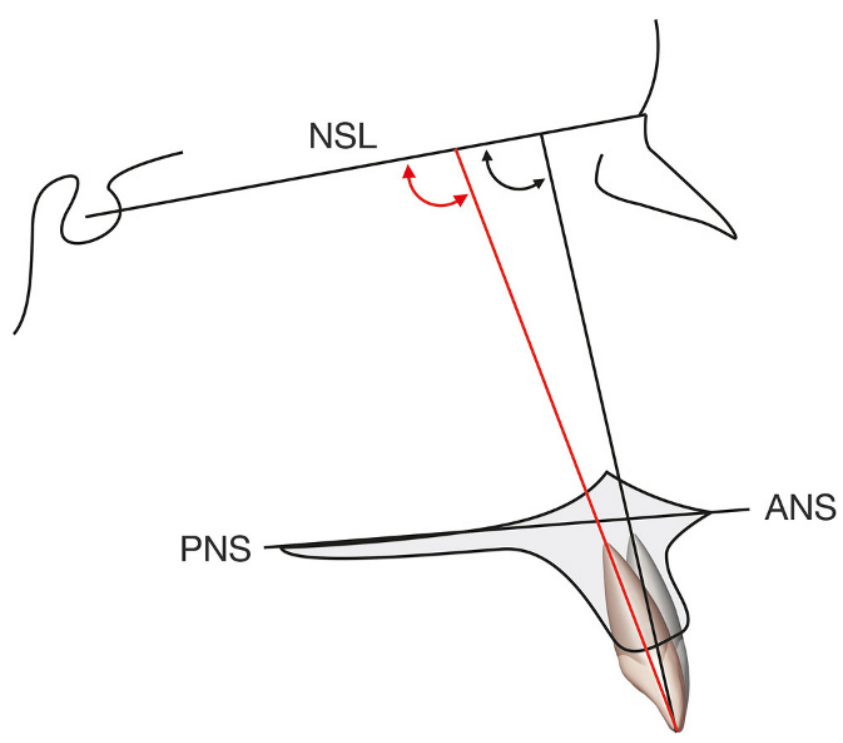

Fig. 4 Analysis of torque change for the maxillary central incisors between pretreatment (black line) and posttreatment (red line) lateral cephalogram relative to the anterior base of the skull and the maxillary base plane

Abb. 4 Analyse der Torqueveränderung der zentralen Oberkieferinzisiven zwischen prä- (schwarze Linie) und posttherapeutischem (rote Linie) Fernröntgenseitenbild zur vorderen Schädelbasis und der Oberkiefergrundebene

\section{Results}

Based on a pretreatment tooth length of $100 \%$, the mean relative root-crown ratio (rRCR) after completion of the orthodontic treatment with the TSA was $93 \%$ and in the orthodontic-treated control group $89 \%$. The difference between the groups was significant $(U=3208, p=0.014$; Table 1). The average rRCR for the individual incisors in the TSA group ranged from 89 to $95 \%$ and in the control group from 87 to $90 \%$ (Table 1, Fig. 5). The individual teeth (tooth 12, 11, 21, and 22) did not differ significantly within both groups (Kruskal-Wallis test; TSA group: $H=7.512$, $\mathrm{df}=3, p=0.057$; control group: $H=1.373, \mathrm{df}=3, p=0.712$ ). But a significant difference was found for tooth 12 between TSA and the control group (92 vs. $96 ; U=236.0, p=0.019$; Table 1, Fig. 5). The median rRCR in the control group was smaller than in the TSA group (Fig. 5).

Concerning the incidence of root resorption, $89 \%$ (TSA group) and $94.4 \%$ (control group) of the teeth examined showed resorptions (Table 2). In the TSA group 8/72 $(11.1 \%)$ teeth were not affected with posttreatment root resorption, in the control group only 5.6\%. The severity of the resorptions was predominantly in the light to moderate range $(55.6 \%$ and $30.6 \%$ within the TSA group and $48.6 \%$ and $33.3 \%$ in the control group). Severe resorption was

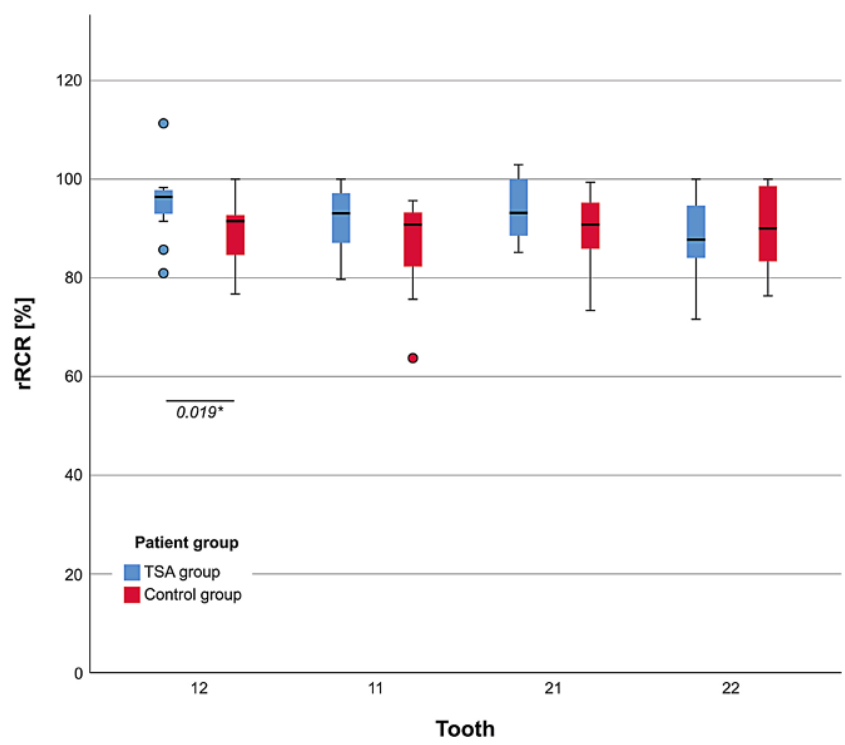

Fig. 5 Relative change in root-crown ratio (rRCR) for tooth 11, 12, 21, 22 , for torque-segmented archwire (TSA) treated and conventionally orthodontic treated patients. Pairwise comparisons were done using the Mann-Whitney U test (asterisk $p<0.05$ ). For the comparison within each patient group the Kruskal-Wallis test was applied $(p<0.05)$

Abb. 5 Relative Änderung des Wurzel-Kronen-Verhältnisses (rRCR) für die Zähne 11, 12, 21 und 22 bei mit TSA (Torquesegmentbogen) sowie konventionell orthodontisch behandelten Patienten. Paarweise Vergleiche wurden mit dem Mann-Whitney-U-Test durchgeführt (Asterisk $p<0,05)$, für den Vergleich innerhalb der Gruppen wurde der Kruskal-Wallis-Test angewendet $(p<0,05)$ 
Table 1 Comparison between the torque-segmented archwire (TSA) and control group concerning the amount of movement of the apices of maxillary incisors in the sagittal and vertical direction relative to the ANS-PNS plane and the relative root-crown ratio (rRCR). Number of patients $(N)$, mean, standard deviation (SD), range (minimum and maximum), median and interquartile range (IQR) were reported. U statistics and significance $(p)$ were given for pairwise comparisons using the Mann-Whitney U test

Tab. 1 Vergleich zwischen TSA(Torquesegmentbogen)- und Kontrollgruppe bezüglich der sagittalen und vertikalen Apexbewegung der Oberkieferfrontzähne und des relativen Wurzel-Kronen-Verhältnisses (rRCR). Anzahl der Patienten $(N)$, Mittelwert, Standardabweichung (SD), Bereich (Minimum, Maximum), Median und das Interquartilsabstand (IQR) wurden dokumentiert. Für die paarweisen Vergleiche mit dem Mann-Whitney-U-Test wurden U-Statistik und $p$-Wert gezeigt

\begin{tabular}{|c|c|c|c|c|c|c|c|c|c|c|c|c|c|c|c|}
\hline & & \multicolumn{12}{|c|}{ Patient group } & \multirow{2}{*}{\multicolumn{2}{|c|}{$\begin{array}{l}\text { Mann- } \\
\text { Whitney } \\
\text { U test }\end{array}$}} \\
\hline & & \multicolumn{6}{|c|}{ TSA group $(N=18)$} & \multicolumn{6}{|c|}{ Control group $(N=18)$} & & \\
\hline & & $\bar{N}$ & Mean & SD & Range & Medic & IQR & $\bar{N}$ & Mean & SD & Range & Medic & IQR & $U$ & $P$ \\
\hline \multirow{4}{*}{$\begin{array}{l}\text { Retrusion/ } \\
\text { protrusion } \\
\text { (sagittal } \\
\text { apex } \\
\text { move- } \\
\text { ment, } \\
\text { mm) }\end{array}$} & Retrusion & 14 & -2.8 & 1.3 & $\begin{array}{l}-5.2 \text { to } \\
-0.9\end{array}$ & -2.4 & $\begin{array}{l}{[-3.2} \\
-2.0]\end{array}$ & 9 & -1.7 & 0.7 & $\begin{array}{l}-2.5 \text { to } \\
-0.5\end{array}$ & -2.0 & $\begin{array}{l}{[-2.0} \\
-1.5]\end{array}$ & 33.0 & 0.062 \\
\hline & $\begin{array}{l}\text { No } \\
\text { move- } \\
\text { ment }\end{array}$ & 0 & - & - & - & - & - & 2 & - & - & - & - & - & - & - \\
\hline & Protrusion & 4 & 1.0 & 0.7 & $\begin{array}{l}0.4 \text { to } \\
2.0\end{array}$ & 0.7 & $\begin{array}{l}{[0.5 ;} \\
1.4]\end{array}$ & 7 & 2.4 & 1.4 & $\begin{array}{l}0.5 \text { to } \\
4.5\end{array}$ & 2.0 & $\begin{array}{l}{[1.5 ;} \\
3.5]\end{array}$ & 6.0 & 0.164 \\
\hline & Total & 18 & -1.9 & 2.0 & $\begin{array}{l}-5.2 \text { to } \\
2.0\end{array}$ & -2.2 & $\begin{array}{l}{[-2.7 ;} \\
-0.9]\end{array}$ & 18 & 0.1 & 2.2 & $\begin{array}{l}-2.5 \text { to } \\
4.5\end{array}$ & -0.2 & $\begin{array}{l}{[-2.0} \\
1.5]\end{array}$ & 83.0 & $0.012 *$ \\
\hline \multirow{4}{*}{$\begin{array}{l}\text { Extrusion/ } \\
\text { intrusion } \\
\text { (vertical } \\
\text { apex } \\
\text { move- } \\
\text { ment, } \\
\text { mm) }\end{array}$} & Intrusion & 5 & -1.1 & 0.7 & $\begin{array}{l}-2.4 \text { to } \\
-0.6\end{array}$ & -0.9 & $\begin{array}{l}{[-0.9 ;} \\
-0.9]\end{array}$ & 2 & -1.0 & 0.0 & $\begin{array}{l}-1.0 \text { to } \\
-1.0\end{array}$ & -1.0 & $\begin{array}{l}{[-1.0} \\
-1.0]\end{array}$ & 8.0 & 0.381 \\
\hline & $\begin{array}{l}\text { No } \\
\text { move- } \\
\text { ment }\end{array}$ & 0 & - & - & - & - & - & 2 & - & - & - & - & - & - & - \\
\hline & Extrusion & 13 & 1.5 & 0.8 & $\begin{array}{l}0.4 \text { to } \\
3.4\end{array}$ & 1.2 & $\begin{array}{l}{[0.9 ;} \\
1.7]\end{array}$ & 14 & 1.8 & 1.0 & $\begin{array}{l}0.5 \text { to } \\
4.0\end{array}$ & 1.5 & $\begin{array}{l}{[1.0 ;} \\
2.3]\end{array}$ & 74.0 & 0.430 \\
\hline & Total & 18 & 0.7 & 1.4 & $\begin{array}{l}-2.4 \text { to } \\
3.4\end{array}$ & 1.0 & $\begin{array}{l}{[-0.6 ;} \\
1.6]\end{array}$ & 18 & 1.3 & 1.3 & $\begin{array}{l}-1.0 \text { to } \\
4.0\end{array}$ & 1.3 & $\begin{array}{l}{[0.5 ;} \\
2.0]\end{array}$ & 134.0 & 0.389 \\
\hline \multirow[t]{7}{*}{ rRCR, \% } & Tooth 11 & 18 & 92 & 6 & $\begin{array}{l}80 \text { to } \\
100\end{array}$ & 93 & $\begin{array}{l}{[87 ;} \\
97]\end{array}$ & 18 & 87 & 8 & $\begin{array}{l}64 \text { to } \\
96\end{array}$ & 91 & $\begin{array}{l}{[82 ;} \\
93]\end{array}$ & 218.0 & 0.079 \\
\hline & Tooth 12 & 18 & 95 & 6 & $\begin{array}{l}81 \text { to } \\
111\end{array}$ & 96 & $\begin{array}{l}{[93 ;} \\
98]\end{array}$ & 18 & 90 & 7 & $\begin{array}{l}77 \text { to } \\
100\end{array}$ & 92 & $\begin{array}{l}{[85 ;} \\
93]\end{array}$ & 236.0 & $0.019 *$ \\
\hline & Tooth 21 & 18 & 94 & 6 & $\begin{array}{l}85 \text { to } \\
103\end{array}$ & 93 & $\begin{array}{l}{[89 ;} \\
100]\end{array}$ & 18 & 90 & 7 & $\begin{array}{l}73 \text { to } \\
99\end{array}$ & 91 & $\begin{array}{l}{[86 ;} \\
95]\end{array}$ & 213.0 & 0.111 \\
\hline & Tooth 22 & 18 & 89 & 7 & $\begin{array}{l}72 \text { to } \\
100\end{array}$ & 88 & $\begin{array}{l}{[84 ;} \\
95]\end{array}$ & 18 & 90 & 9 & $\begin{array}{l}76 \text { to } \\
100\end{array}$ & 90 & $\begin{array}{l}{[83 ;} \\
99]\end{array}$ & 136.5 & 0.424 \\
\hline & $\begin{array}{l}\text { Central } \\
\text { incisors }\end{array}$ & 36 & 93 & 6 & $\begin{array}{l}80 \text { to } \\
103\end{array}$ & 93 & $\begin{array}{l}{[88 ;} \\
97]\end{array}$ & 36 & 88 & 8 & $\begin{array}{l}64 \text { to } \\
99\end{array}$ & 91 & $\begin{array}{l}{[83 ;} \\
94]\end{array}$ & 441.5 & $0.020^{*}$ \\
\hline & $\begin{array}{l}\text { Lateral } \\
\text { incisors }\end{array}$ & 36 & 92 & 7 & $\begin{array}{l}72 \text { to } \\
111\end{array}$ & 94 & $\begin{array}{l}{[86 ;} \\
97]\end{array}$ & 36 & 90 & 8 & $\begin{array}{l}76 \text { to } \\
100\end{array}$ & 91 & $\begin{array}{l}{[84 ;} \\
98]\end{array}$ & 573.5 & 0.401 \\
\hline & Total & 72 & 93 & 6 & $\begin{array}{l}72 \text { to } \\
111\end{array}$ & 93 & $\begin{array}{l}{[87 ;} \\
97]\end{array}$ & 72 & 89 & 8 & $\begin{array}{l}64 \text { to } \\
100\end{array}$ & 91 & $\begin{array}{l}{[84 ;} \\
95]\end{array}$ & 3208.0 & $0.014^{*}$ \\
\hline
\end{tabular}

present in $2.8 \%$ of the TSA group and $12.5 \%$ of the control group.

Evaluation of the lateral cephalograms showed that the main directions of movement of the apices of the upper central incisors were retrusion and extrusion (Table 1). The median sagittal apex movement of the total TSA group $(-2.2 \mathrm{~mm})$ was statistically significant larger than that of the control group (median: $-0.2 \mathrm{~mm} ; U=83.0, p=0.012$ ), whereas there was no statistical difference in vertical apex movement ( $U=134.0, p=0.389$; Table 1$)$.

Regarding the axial position of the front teeth, the median of the front tooth axis (1_NSL) significantly increased in the TSA group from 98.2 to $102.5^{\circ}(Z=-2.286, p=0.022$; Table 3). In the control group, no significant change in the axial position $(Z=-1.613, p=0.107)$ was observed (Table 3).

Pearson's correlation coefficients for resorptions at maxillary incisors and horizontal direction of apical movement were $r=0.136(p=0.255)$ for the TSA group and $r=0.042$ $(p=0.727)$ for the control group and were not statistically significant (Fig. 6a). For resorptions at maxillary incisors and vertical direction of apical movements the Pearson's correlation coefficients were $r=0.067(p=0.575)$ for the TSA group and $r=-0.007(p=0.950)$ for the control group 
Table 2 Severity of root resorption (RR). Crosstabulation of tooth and patient group with levels of severity of root resorption classified according to relative root-crown ratio (rRCR)

Tab. 2 Schweregrad der Wurzelresorption (RR). Kreuztabelle aus Zahn und Patientengruppe mit dem Niveau des Schweregrades der Wurzelresorption entsprechend des relativen Wurzel-Kronen-Verhältnisses (rRCR)

\begin{tabular}{|c|c|c|c|c|c|c|c|c|c|c|c|}
\hline \multirow{2}{*}{$\begin{array}{l}\text { Severity } \\
\text { of RR }\end{array}$} & & \multicolumn{2}{|l|}{12} & \multicolumn{2}{|l|}{11} & \multicolumn{2}{|l|}{21} & \multicolumn{2}{|l|}{22} & \multicolumn{2}{|l|}{ Total } \\
\hline & & $\begin{array}{l}\text { TSA } \\
\text { group }\end{array}$ & $\begin{array}{l}\text { Control } \\
\text { group }\end{array}$ & $\begin{array}{l}\text { TSA } \\
\text { group }\end{array}$ & $\begin{array}{l}\text { Control } \\
\text { group }\end{array}$ & $\begin{array}{l}\text { TSA } \\
\text { group }\end{array}$ & $\begin{array}{l}\text { Control } \\
\text { group }\end{array}$ & $\begin{array}{l}\text { TSA } \\
\text { group }\end{array}$ & $\begin{array}{l}\text { Control } \\
\text { group }\end{array}$ & $\begin{array}{l}\text { TSA } \\
\text { group }\end{array}$ & $\begin{array}{l}\text { Control } \\
\text { group }\end{array}$ \\
\hline \multirow{2}{*}{$\begin{array}{l}\text { No RR } \\
\text { (rRCR } \\
\geq 100 \% \text { ) }\end{array}$} & $\begin{array}{l}\text { No. of } \\
\text { teeth }\end{array}$ & 1 & 1 & 1 & 0 & 5 & 0 & 1 & 3 & 8 & 4 \\
\hline & $\%$ & 5.6 & 5.6 & 5.6 & 0.0 & 27.8 & 0.0 & 5.6 & 16.7 & 11.1 & 5.6 \\
\hline \multirow{2}{*}{$\begin{array}{l}\text { Slight RR } \\
(90 \leq \mathrm{x}< \\
100)\end{array}$} & $\begin{array}{l}\text { No. of } \\
\text { teeth }\end{array}$ & 15 & 9 & 10 & 10 & 8 & 10 & 7 & 6 & 40 & 35 \\
\hline & $\%$ & 83.3 & 50.0 & 55.6 & 55.6 & 44.4 & 55.6 & 38.9 & 33.3 & 55.6 & 48.6 \\
\hline \multirow{2}{*}{$\begin{array}{l}\text { Moderate } \\
\text { RR } \\
(80 \leq x<90)\end{array}$} & $\begin{array}{l}\text { No. of } \\
\text { teeth }\end{array}$ & 2 & 6 & 6 & 6 & 5 & 6 & 9 & 6 & 22 & 24 \\
\hline & $\%$ & 11.1 & 33.3 & 33.3 & 33.3 & 27.8 & 33.3 & 50.0 & 33.3 & 30.6 & 33.3 \\
\hline \multirow{2}{*}{$\begin{array}{l}\text { Severe } \\
\mathrm{RR} \\
(<80)\end{array}$} & $\begin{array}{l}\text { No. of } \\
\text { teeth }\end{array}$ & 0 & 2 & 1 & 2 & 0 & 2 & 1 & 3 & 2 & 9 \\
\hline & $\%$ & 0.0 & 11.1 & 5.6 & 11.1 & 0.0 & 11.1 & 5.6 & 16.7 & 2.8 & 12.5 \\
\hline \multirow[t]{2}{*}{ Total } & $\begin{array}{l}\text { No. of } \\
\text { teeth }\end{array}$ & 18 & 18 & 18 & 18 & 18 & 18 & 18 & 18 & 72 & 72 \\
\hline & $\%$ & 100.0 & 100.0 & 100.0 & 100.0 & 100.0 & 100.0 & 100.0 & 100.0 & 100 & 100 \\
\hline
\end{tabular}

TSA torque-segmented archwire

Table 3 Magnitude of torque of maxillary central incisors relative to the anterior base of the skull and the ANS-PNS plane for both patient groups. Number of patients $(N)$, mean, standard deviation (SD), range (minimum and maximum), median and interquartile range (IQR) were reported. $Z$ statistics and significance $(p)$ were given for pairwise comparisons of repeated measurements using the Wilcoxon signed-rank test

Tab. 3 Torqueausmaß zentraler Oberkieferfrontzähne in Bezug auf die vordere Schädelbasis und der ANS-PNS-Ebene für beide Patientengruppen. Anzahl der Patienten $(N)$, Mittelwert, Standardabweichung (SD), Bereich (Minimum und Maximum), Median und der Interquartilsabstand (IQR) wurden dokumentiert. Für die paarweisen Vergleiche mit dem Wilcoxon-Vorzeichen-Rang-Test wurden Z-Statistik und $p$-Wert zusammengestellt

\begin{tabular}{|c|c|c|c|c|c|c|c|c|c|c|c|c|c|}
\hline \multirow[t]{3}{*}{$\begin{array}{l}\text { Patient } \\
\text { group }\end{array}$} & \multirow[t]{3}{*}{$\begin{array}{l}\text { Measure- } \\
\text { ment }\end{array}$} & \multicolumn{10}{|c|}{ Treatment step } & \multicolumn{2}{|c|}{$\begin{array}{l}\text { Wilcoxon } \\
\text { signed-rank test }\end{array}$} \\
\hline & & \multicolumn{5}{|c|}{ Pretreatment $(N=18)$} & \multicolumn{5}{|c|}{ Posttreatment $(N=18)$} & \multirow[b]{2}{*}{$Z$} & \multirow[b]{2}{*}{$p$} \\
\hline & & Mean & SD & Range & Median & IQR & Mean & SD & Range & Median & IQR & & \\
\hline \multirow[t]{2}{*}{$\begin{array}{l}\text { TSA } \\
\text { group }\end{array}$} & $\begin{array}{l}\text { 1_NSL } \\
{\left[{ }^{\circ}\right]}\end{array}$ & 96.5 & 7.7 & $\begin{array}{l}80.6 \text { to } \\
109.4\end{array}$ & 98.2 & $\begin{array}{l}{[90.0} \\
102.4]\end{array}$ & 101.3 & 6.1 & $\begin{array}{l}85.3 \text { to } \\
109.8\end{array}$ & 102.5 & $\begin{array}{l}{[98.2 ;} \\
104.2]\end{array}$ & -2.286 & $0.022 *$ \\
\hline & $\begin{array}{l}\text { 1_NL } \\
{\left[{ }^{\circ}\right]}\end{array}$ & 103.1 & 7.7 & $\begin{array}{l}87.3 \text { to } \\
113.6\end{array}$ & 105.3 & $\begin{array}{l}{[95.4} \\
108.8]\end{array}$ & 109.4 & 6.8 & $\begin{array}{l}92.7 \text { to } \\
124.5\end{array}$ & 110.1 & $\begin{array}{l}{[106.8 ;} \\
111.9]\end{array}$ & -3.114 & $0.002 *$ \\
\hline \multirow[t]{2}{*}{$\begin{array}{l}\text { Control } \\
\text { group }\end{array}$} & $\begin{array}{l}\text { 1_NSL } \\
{\left[{ }^{\circ}\right]}\end{array}$ & 102.8 & 8.2 & $\begin{array}{l}80.0 \text { to } \\
115.0\end{array}$ & 104.0 & $\begin{array}{l}{[98.0} \\
109.0]\end{array}$ & 106.8 & 6.7 & $\begin{array}{l}88.5 \text { to } \\
120.5\end{array}$ & 107.5 & $\begin{array}{l}{[105.5 ;} \\
111.0]\end{array}$ & -1.613 & 0.107 \\
\hline & $\begin{array}{l}\text { 1_NL } \\
{\left[{ }^{\circ}\right]}\end{array}$ & 110.1 & 6.9 & $\begin{array}{l}95.0 \text { to } \\
121.0\end{array}$ & 110.5 & $\begin{array}{l}{[107.0 ;} \\
114.0]\end{array}$ & 114.3 & 5.3 & $\begin{array}{l}100.0 \text { to } \\
123.0\end{array}$ & 115.0 & $\begin{array}{l}{[112.0 ;} \\
117.5]\end{array}$ & -1.918 & 0.055 \\
\hline
\end{tabular}

TSA torque-segmented archwire

and were not statistically significant (Fig. 6b). Both correlation coefficients show that there is no linear correlation between horizontal or vertical direction of movement of the apex and the amount of resorption of upper incisors. A correlation between resorption at maxillary incisors and change in both toot axis 1_NSL (Fig. 7a) and 1_NL (Fig. 7b) was not evident in the TSA group (1_NSL: $\left.r=0.139, p=0.243 ; 1 \_\mathrm{NL}: r=0.172, p=0.148\right)$ nor in the control group (1_NSL: $r=0.094, p=0.430 ; 1 \_\mathrm{NL}$ : $r=0.066, p=0.584)$. The correlation coefficients show that there is no linear correlation between change in tooth axis 1_NSL or 1_NL and the amount of resorption of upper incisors. The $p$-values calculated were not statistically significant, given a level of significance of $p<0.05$.

The effect of treatment duration on the amount of resorption of upper incisors was not significant in either patient group. Pearson's correlation coefficient was $r=0.195$ $(p=0.101)$ for the TSA group and $r=0.068(p=0.571)$ for the control group. 

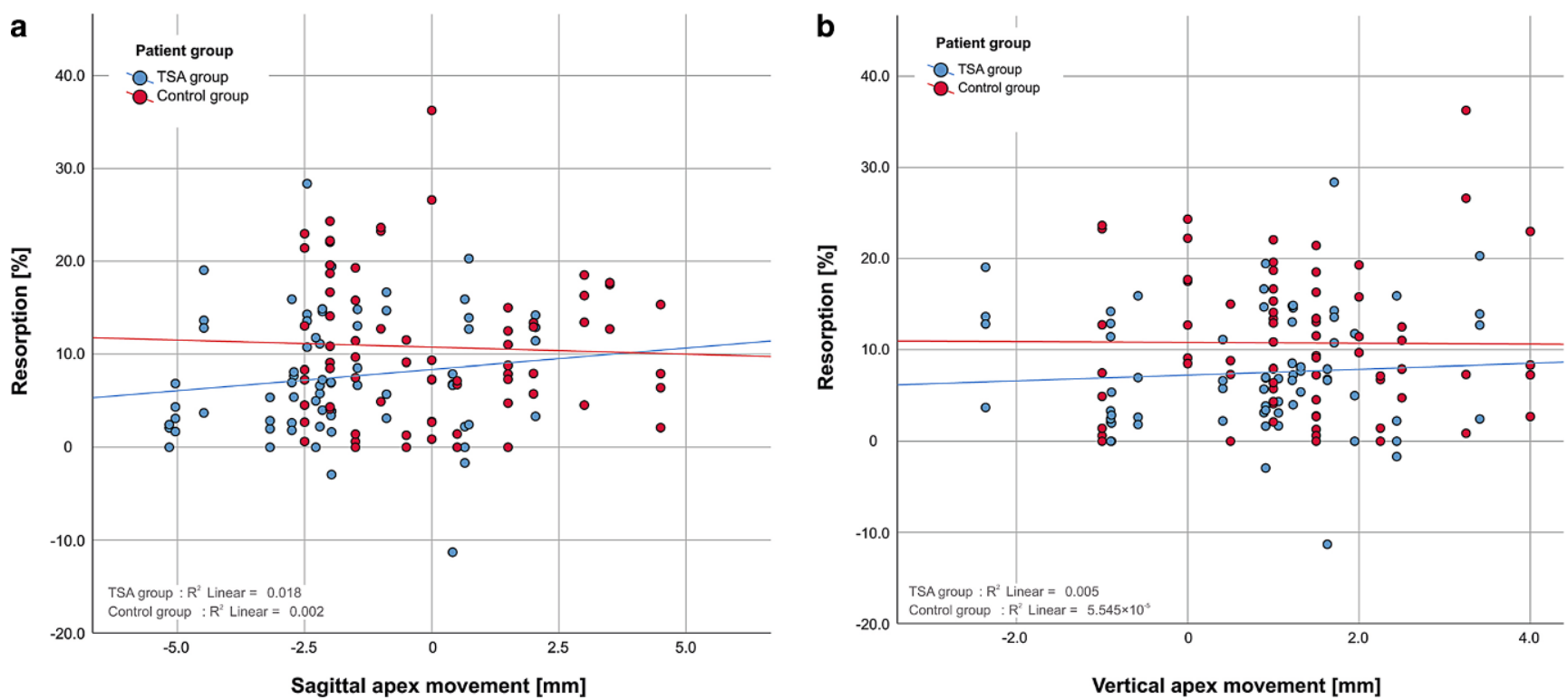

Fig. 6 a Relationship between resorption of the central and lateral incisors and sagittal apex movement for both patient groups. No significant correlation between sagittal apex movement and resorption was found in either group. b Relationship between resorption of the central and lateral incisors and vertical apex movement for both patient groups. No significant correlation between vertical apex movement and resorption was found in either group. TSA torque-segmented archwire

Abb. 6 a Beziehung zwischen Wurzelresorption der zentralen und lateralen Schneidezähne und der sagittalen Apexbewegung in beiden Patientengruppen. Eine signifikante Korrelation zwischen sagittaler Apexbewegung und Resorption ließ sich in beiden Gruppen nicht feststellen. b Beziehung zwischen Wurzelresorption der zentralen und lateralen Schneidezähne und der vertikalen Apexbewegung in beiden Gruppen. Eine signifikante Korrelation zwischen vertikaler Apexbewegung und Resorption konnte in beiden Gruppen nicht festgestellt werden

\section{Discussion}

The accurate and controlled biomechanics of the TSA [47, 55] makes it possible to exert defined moments on the teeth and thereby achieve clinically very efficient results $[3,47]$. The results also show that within a 1_NSL range of $85.3-109.8^{\circ}$ torque adjustment with defined moments even with preactivated torque wires remains difficult. In addition, biomechanical and biological factors can play a role. Torque can be applied with stainless steel arch wires as well as the TSA. The inconsistency of data between the two methods shows that clinically the adjustment of the M/F ratio depends on other factors. The application of the TSA simplifies clinical application of torque. However prospectively, for better M/F ratio control different moments should be used. For bodily retraction, moments in the range of 15-20 Nmm are reported [5, 9, 14], whereas for controlled tipping lower moments can be applied. Further clinical studies must show whether this will lead to a better adjustment of the $\mathrm{M} / \mathrm{F}$ ratio.

In most of the studies on continuous forces and moments, there was nevertheless a loss of force or moment during the progress of the treatment [1, 30, 36-38], although the study design in these studies is generally a matter of discussion. The torque we used on the four maxillary incisors with an overall magnitude of 15-20 Nmm [55] is within the physiological range of the ideal level of torque $[5,9,14]$. This torque range is discussed in order to minimize resorptions at the apical root tip [10, 12, 13, 18, 19, 21, 24, 42, 44, 48].

The methodology to assess the resorption rate during orthodontic treatment applied in our study is known from the literature and well established $[15,16,26]$. It allows use of X-rays, which are recorded in the diagnostic routine of an orthodontic treatment. Therefore, it avoids additional radiation exposure of the patient. As panoramic radiographs are accompanied by perspective distortions, the use of the relative root-to-crown ratio (rRCR) allows one to calculate a decresase in root length [15]. With the assumption of a constant crown length, these distortions are compensated. A much more detailed analysis of root resorptions is only possible using three-dimensional radiographic techniques like cone-beam computed tomography [4, 43]. Unfortunately, these X-ray techniques are accompanied by high additional radiation exposure and have a strong indication.

The average loss of apical root length (rRCR) of $7 \%$ in the TSA group and $11 \%$ in the control group recorded in the present study can be regarded as not clinically relevant. The median rRCR of the maxillary incisors was significant larger in the TSA group as compared to the control group. Therefore, root resorption was less expressed in the TSA group although the difference was only $2 \%$. In our study, no significant differences were found between the maxillary incisors within one group and between the groups except tooth 12 . Our results for the maxillary central incisor coin- 

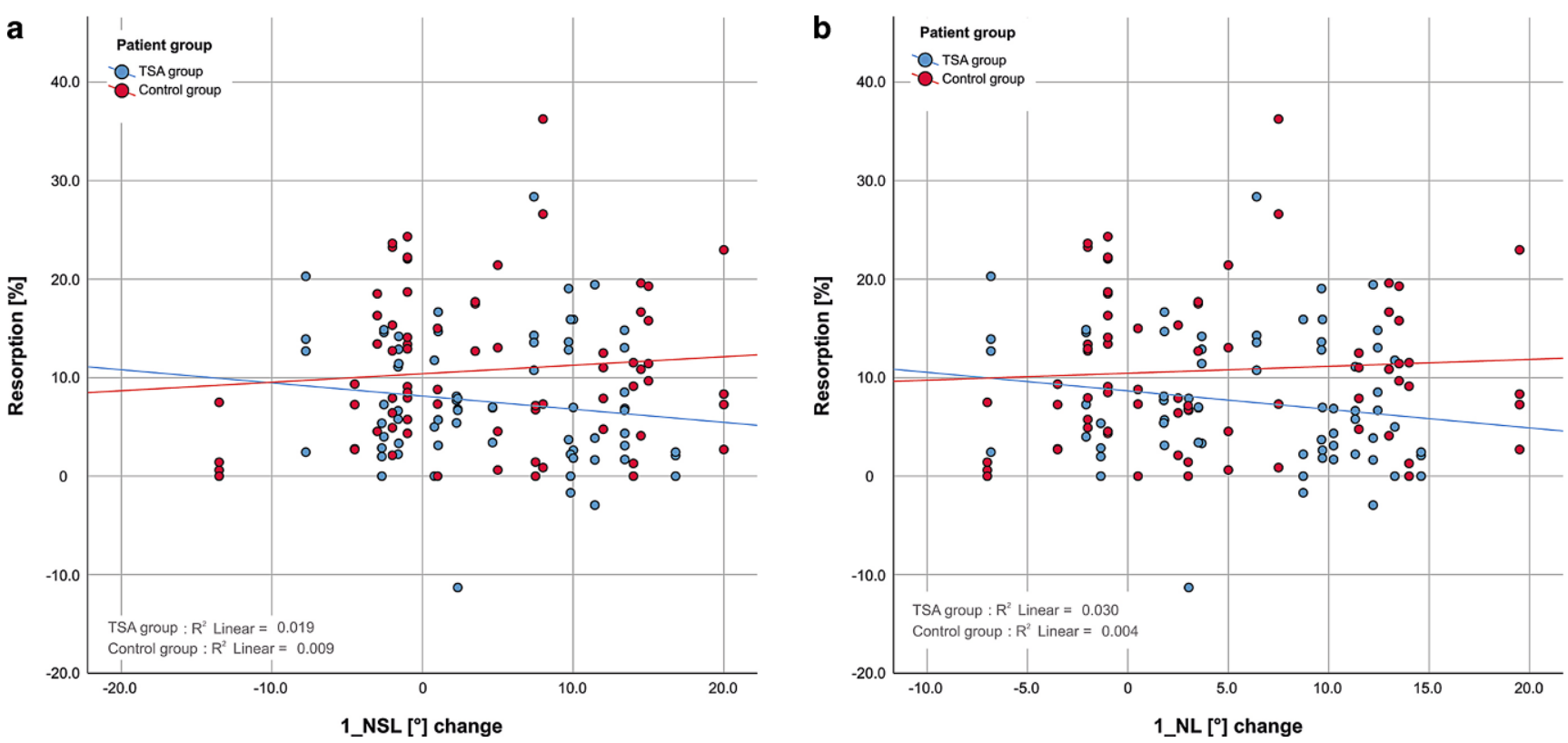

Fig. 7 a Relationship between resorption of the central and lateral incisors and 1_NSL change for both patient groups. No significant correlation between 1_NSL change and resorption was found in either group. b Relationship between resorption of the central and lateral incisors and 1_NL change for both patient groups. No significant correlation between change of 1_NL and resorption was found in either group. TSA torque-segmented archwire

Abb. 7 a Beziehung zwischen Wurzelresorption der zentralen und lateralen Schneidezähne und 1_NSL-Änderung in beiden Patientengruppen. Eine signifikante Korrelation zwischen 1_NSL-Änderung und Resorption konnte in beiden Gruppen nicht festgestellt werden. b Beziehung zwischen Wurzelresorption der zentralen und lateralen Schneidezähne und 1_NL-Änderung in beiden Gruppen. Eine signifikante Korrelation zwischen Änderung des 1_NL und Resorption ließ sich in beiden Gruppen nicht feststellen

cide with the amount of resorption recorded in most other studies that analyzed the extent of root resorption found on upper central incisors after orthodontic treatment with fixed appliances $[7,12,15,22,29,32,40,43,50]$. In the present study, however, no statistically significant correlation was noted for resorptions and treatment-related apical movement in the horizontal or vertical direction. On a cautionary note, however, it should be mentioned that the apical movement distances were calculated on the lateral cephalograms, for which the interval between pre- and posttreatment X-rays does not always coincide precisely with the period when the TSA is in place. Hence, a treatmentrelated unwanted jiggling effect in other treatment phases cannot be ruled out as an important contributory factor to root resorption. The major advantage of utilizing the superelasticity of these materials for the practitioner is that, even if the wire is excessively activated, the torque acting on the tooth remains within physiological limits. Hence, rectangular wires can be used even at an early stage; these allow better control of tooth movement, especially during torque application [52]. An evaluative comparison of the different types of moment application is only possible if a controlled comparative test is done in the same individual, e.g., by applying a split-mouth design, but this is clinically not realistic.
No correlation between root resorption and incisor axis change was found in our study. A review of the literature shows that there are contradictory findings concerning this correlation [12, 32, 40,41]. Multifactorial influences on the amount of root resorption are discussed. Due to the variety of study designs, no consistent statement is found in the literature. Most of the authors have not found any correlation between the difference of incisor inclination and root resorption [12, 32, 40, 41].

Although we found no significant correlation $(p \geq 0.101)$ between duration of torque application and root resorption, it seems reasonable to assume that the amount and the duration of the torque application have an influence on the grade of root resorption [10,45]. A longer treatment duration is associated with significantly higher root resorption rates for maxillary central incisors [20, 25, 49]. Only a few studies deal with the time dependence of treatment-related root resorption when continuous forces are applied by means of NiTi components [10, 35]. Although the correlation was not significant in our study, there was a trend towards an increased risk of root resorption with a longer treatment duration.

The results of this study show no correlation between vertical and sagittal apex movement and root resorption. This correlation is controversially discussed in the literature $[7,12,15,22,29,32,43,50]$. Factors like study de- 
sign, patient number and methodology should be discussed. In 4 patients from the TSA group and 7 patients from the control group, a sagittal apex movement of 1 or $2 \mathrm{~mm}$ was observed, respectively. This indicates an uncontrolled tipping of the incisors. This effect arises due to differences in root geometry and nonideal force-moment application.

The results of this retrospective study should be validated with further prospective studies with a larger patient group and measurements of the actual torque moment acting on the teeth, to gain more knowledge about the ideal level of moment for continuous torque application, and to obtain more clear-cut results.

\section{Conclusion}

- Use of the torque-segmented archwire (TSA) for continuous torque application on the maxillary anterior teeth leads to slight, clinically nonrelevant apical root resorption.

- The incisors axis in the TSA group was on average significantly improved. Independently, though defined moments were applied, the adjustment of the M/F ratio was still problematic. In order to achieve a better adjustment of the $\mathrm{M} / \mathrm{F}$ ratio, the application of different moments is advised.

- No differences were found between the amount of apical root resorption of maxillary lateral and central incisors in the TSA and control groups.

- Between the TSA and control group significant differences in the relative root-crown ratio (rRCR) were found for tooth 12 , the central incisors, and for all maxillary incisors. Although root resorption in the TSA group was less pronounced, the difference between the groups was only $2 \%$.

- There is no correlation between root resorption and treatment duration, the distance of vertical and sagittal movement of the apex and the change in inclination of the incisal axis relative to the anterior base of the skull.

Funding Open Access funding provided by Projekt DEAL.

\section{Compliance with ethical guidelines}

Conflict of interest A. Wichelhaus, M. Dulla, H. Sabbagh, U. Baumert and $\mathrm{T}$. Stocker declare that they have no competing interests.

Ethical standards All procedures performed in studies involving human participants or on human tissue were in accordance with the ethical standards of the institutional and/or national research committee and with the 1975 Helsinki declaration and its later amendments or comparable ethical standards. The local ethics committee approved the study protocol (project number 19-815). Informed consent was obtained from all individual participants included in the study.
Open Access This article is licensed under a Creative Commons Attribution 4.0 International License, which permits use, sharing, adaptation, distribution and reproduction in any medium or format, as long as you give appropriate credit to the original author(s) and the source, provide a link to the Creative Commons licence, and indicate if changes were made. The images or other third party material in this article are included in the article's Creative Commons licence, unless indicated otherwise in a credit line to the material. If material is not included in the article's Creative Commons licence and your intended use is not permitted by statutory regulation or exceeds the permitted use, you will need to obtain permission directly from the copyright holder. To view a copy of this licence, visit http://creativecommons.org/licenses/by/4. $0 /$.

\section{References}

1. Acar A, Canyurek U, Kocaaga M, Erverdi N (1999) Continuous vs. discontinuous force application and root resorption. Angle Orthod 69:159-163. https://doi.org/10.1043/0003-3219(1999)069<0159: cvdfaa > 2.3.co;2 (discussion 163-154)

2. Apajalahti S, Peltola JS (2007) Apical root resorption after orthodontic treatment-a retrospective study. Eur J Orthod 29:408 412. https://doi.org/10.1093/ejo/cjm016

3. Aras B, Cheng LL, Turk T, Elekdag-Turk S, Jones AS, Darendeliler MA (2012) Physical properties of root cementum: part 23. Effects of 2 or 3 weekly reactivated continuous or intermittent orthodontic forces on root resorption and tooth movement: a microcomputed tomography study. Am J Orthod Dentofacial Orthop 141:e29-e37. https://doi.org/10.1016/j.ajodo.2011.07.018

4. Aras I, Unal I, Huniler G, Aras A (2018) Root resorption due to orthodontic treatment using self-ligating and conventional brackets : A cone-beam computed tomography study. J Orofac Orthop 79:181-190. https://doi.org/10.1007/s00056-018-0133-5

5. Bantleon HP, Droschl H (1988) Front torque using a partial arch technic. Fortschr Kieferorthop 49:203-212. https://doi.org/10. 1007/bf02163378

6. Bartzela TN, Senn C, Wichelhaus A (2007) Load-deflection characteristics of superelastic nickel-titanium wires. Angle Orthod 77:991-998. https://doi.org/10.2319/101206-423.1

7. Baumrind S, Korn EL, Boyd RL (1996) Apical root resorption in orthodontically treated adults. Am J Orthod Dentofacial Orthop 110:311-320

8. Brauchli LM, Steineck M, Wichelhaus A (2012) Active and passive self-ligation: a myth? Part 1: torque control. Angle Orthod 82:663-669. https://doi.org/10.2319/062011-673.1

9. Burstone CJ (1966) The mechanics of the segmented arch techniques. Angle Orthod 36:99-120. https://doi.org/10.1043/00033219(1966)036〈0099:TMOTSA) 2.0.CO;2

10. Casa MA, Faltin RM, Faltin K, Sander FG, Arana-Chavez VE (2001) Root resorptions in upper first premolars after application of continuous torque moment. Intra-individual study. J Orofac Orthop 62:285-295

11. Creekmore TD (1979) Dr. Thomas D. Creekmore on torque. J Clin Orthod 13:305-310

12. DeShields RW (1969) A study of root resorption in treated Class II, Division I malocclusions. Angle Orthod 39:231-245. https://doi.org/10.1043/0003-3219(1969)039〈0231:asorri〉2.0.co;2

13. Faltin RM, Arana-Chavez VE, Faltin K, Sander FG, Wichelhaus A (1998) Root resorptions in upper first premolars after application of continuous intrusive forces. Intra-individual study. J Orofac Orthop 59:208-219

14. Feldner JC, Sarkar NK, Sheridan JJ, Lancaster DM (1994) In vitro torque-deformation characteristics of orthodontic polycarbonate 
brackets. Am J Orthod Dentofacial Orthop 106:265-272. https:// doi.org/10.1016/S0889-5406(94)70046-X

15. Fritz U, Diedrich P, Wiechmann D (2003) Apical root resorption after lingual orthodontic therapy. J Orofac Orthop 64:434-442. https://doi.org/10.1007/s00056-003-0243-5

16. Gay G, Ravera S, Castroflorio T, Garino F, Rossini G, Parrini S, Cugliari G, Deregibus A (2017) Root resorption during orthodontic treatment with Invisalign(R): a radiometric study. Prog Orthod 18:12. https://doi.org/10.1186/s40510-017-0166-0

17. Goel P, Tandon R, Agrawal KK (2014) A comparative study of different intrusion methods and their effect on maxillary incisors. J Oral Biol Craniofac Res 4:186-191. https://doi.org/10.1016/j. jobcr.2014.11.007

18. Goldin B (1989) Labial root torque: effect on the maxilla and incisor root apex. Am J Orthod Dentofacial Orthop 95:208-219

19. Goldson L, Henrikson CO (1975) Root resorption during Begg treatment; a longitudinal roentgenologic study. Am J Orthod 68:55-66

20. Harris EF, Baker WC (1990) Loss of root length and crestal bone height before and during treatment in adolescent and adult orthodontic patients. Am J Orthod Dentofac Orthop 98:463-469

21. Harris EF, Butler ML (1992) Patterns of incisor root resorption before and after orthodontic correction in cases with anterior open bites. Am J Orthod Dentofacial Orthop 101:112-119. https://doi. org/10.1016/0889-5406(92)70002-r

22. Ho KH, Liao YF (2012) Pre-treatment radiographic features predict root resorption of treated impacted maxillary central incisors. Orthod Craniofac Res 15:198-205. https://doi.org/10.1111/j.16016343.2012.01545.x

23. Janson GR, De Luca Canto G, Martins DR, Henriques JF, De Freitas MR (2000) A radiographic comparison of apical root resorption after orthodontic treatment with 3 different fixed appliance techniques. Am J Orthod Dentofac Orthop 118:262-273. https://doi. org $/ 10.1067 / \bmod .2000 .99136$

24. Kaley J, Phillips C (1991) Factors related to root resorption in edgewise practice. Angle Orthod 61:125-132. https://doi.org/10.1043/ 0003-3219(1991)061<0125:frtrri>2.0.co;2

25. Kalha AS, Kachiwala VA, Govardhan SN, McLaughlin RP, Khurshaid SZ (2010) Redefining orthodontic space closure: sequential repetitive loading of the periodontal ligament-a clinical study. World J Orthod 11:221-229

26. Krieger E, Drechsler T, Schmidtmann I, Jacobs C, Haag S, Wehrbein H (2013) Apical root resorption during orthodontic treatment with aligners? A retrospective radiometric study. Head Face Med 9:21. https://doi.org/10.1186/1746-160X-9-21

27. Linge BO, Linge L (1983) Apical root resorption in upper anterior teeth. Eur J Orthod 5:173-183. https://doi.org/10.1093/ejo/5.3.173

28. Linge L, Linge BO (1991) Patient characteristics and treatment variables associated with apical root resorption during orthodontic treatment. Am J Orthod Dentofacial Orthop 99:35-43. https://doi. org/10.1016/s0889-5406(05)81678-6

29. Liou EJ, Chang PM (2010) Apical root resorption in orthodontic patients with en-masse maxillary anterior retraction and intrusion with miniscrews. Am J Orthod Dentofac Orthop 137:207-212. https:// doi.org/10.1016/j.ajodo.2008.02.027

30. Lundgren D, Owman-Moll P, Kurol J, Martensson B (1996) Accuracy of orthodontic force and tooth movement measurements. Br J Orthod 23:241-248

31. Martins DR, Tibola D, Janson G, Maria FR (2012) Effects of intrusion combined with anterior retraction on apical root resorption. Eur J Orthod 34:170-175. https://doi.org/10.1093/ejo/cjq178

32. Mirabella AD, Artun J (1995) Risk factors for apical root resorption of maxillary anterior teeth in adult orthodontic patients. Am J Orthod Dentofac Orthop 108:48-55. https://doi.org/10.1016/s08895406(95)70065-x
33. Motokawa M, Sasamoto T, Kaku M, Kawata T, Matsuda Y, Terao A, Tanne K (2012) Association between root resorption incident to orthodontic treatment and treatment factors. Eur J Orthod 34:350-356. https://doi.org/10.1093/ejo/cjr018

34. Nakano T, Hotokezaka H, Hashimoto M, Sirisoontorn I, Arita K, Kurohama T, Darendeliler MA, Yoshida N (2014) Effects of different types of tooth movement and force magnitudes on the amount of tooth movement and root resorption in rats. Angle Orthod 84:1079-1085. https://doi.org/10.2319/121913-929.1

35. Noda K, Arai C, Nakamura Y (2010) Root resorption after experimental tooth movement using superelastic forces in the rat. Eur J Orthod 32:681-687. https://doi.org/10.1093/ejo/cjq016

36. Owman-Moll P, Kurol J, Lundgren D (1995) Continuous versus interrupted continuous orthodontic force related to early tooth movement and root resorption. Angle Orthod 65:395-401. https://doi.org/10.1043/0003-3219(1995)065〈0395:cvicof〉2.0.co;2 (discussion 401-392)

37. Owman-Moll P, Kurol J, Lundgren D (1996) Effects of a doubled orthodontic force magnitude on tooth movement and root resorptions. An inter-individual study in adolescents. Eur J Orthod $18: 141-150$

38. Owman-Moll P, Kurol J, Lundgren D (1996) The effects of a fourfold increased orthodontic force magnitude on tooth movement and root resorptions. An intra-individual study in adolescents. Eur J Orthod 18:287-294

39. Papageorgiou SN, Sifakakis I, Doulis I, Eliades T, Bourauel C (2016) Torque efficiency of square and rectangular archwires into 0.018 and 0.022 in. conventional brackets. Prog Orthod 17:5. https://doi.org/10.1186/s40510-016-0118-0

40. Parker RJ, Harris EF (1998) Directions of orthodontic tooth movements associated with external apical root resorption of the maxillary central incisor. Am J Orthod Dentofacial Orthop 114:677-683

41. Phillips JR (1955) Apical root resorption under orthodontic therapy. Angle Orthod 25:1-22. https://doi.org/10.1043/0003-3219(1955) 025<0001:arruot>2.0.co; 2

42. Plets JH, Isaacson RJ, Speidel TM, Worms FW (1974) Maxillary central incisor root length in orthodontically treated and untreated patients. Angle Orthod 44:43-47. https://doi.org/10.1043/00033219(1974)044〈0043:mcirli〉2.0.co;2

43. Puttaravuttiporn $\mathrm{P}$, Wongsuwanlert $\mathrm{M}$, Charoemratrote $\mathrm{C}$, Leethanakul $\mathrm{C}$ (2018) Volumetric evaluation of root resorption on the upper incisors using cone beam computed tomography after 1 year of orthodontic treatment in adult patients with marginal bone loss. Angle Orthod 88:710-718. https://doi.org/10.2319/121717-868.1

44. Remington DN, Joondeph DR, Artun J, Riedel RA, Chapko MK (1989) Long-term evaluation of root resorption occurring during orthodontic treatment. Am J Orthod Dentofacial Orthop 96:43-46

45. Roscoe MG, Meira JB, Cattaneo PM (2015) Association of orthodontic force system and root resorption: a systematic review. Am J Orthod Dentofacial Orthop 147:610-626. https://doi.org/10.1016/ j.ajodo.2014.12.026

46. Sameshima GT, Sinclair PM (2001) Predicting and preventing root resorption: Part I. Diagnostic factors. Am J Orthod Dentofac Orthop 119:505-510. https://doi.org/10.1067/mod.2001.113409

47. Sander FG, Wichelhaus A (1995) Clinical experiences with the torque-segmented arch (TSA). Fortschr Kieferorthop 56:194-201. https://doi.org/10.1007/bf02168132

48. Spurrier SW, Hall SH, Joondeph DR, Shapiro PA, Riedel RA (1990) A comparison of apical root resorption during orthodontic treatment in endodontically treated and vital teeth. Am J Orthod Dentofacial Orthop 97:130-134. https://doi.org/10.1016/08895406(90)70086-r

49. Taithongchai R, Sookkorn K, Killiany DM (1996) Facial and dentoalveolar structure and the prediction of apical root shortening. Am J Orthod Dentofacial Orthop 110:296-302 
50. Tieu LD, Saltaji H, Normando D, Flores-Mir C (2014) Radiologically determined orthodontically induced external apical root resorption in incisors after non-surgical orthodontic treatment of class II division 1 malocclusion: a systematic review. Prog Orthod 15:48. https://doi.org/10.1186/s40510-014-0048-7

51. Topkara A, Karaman AI, Kau CH (2012) Apical root resorption caused by orthodontic forces: A brief review and a long-term observation. Eur J Dent 6:445-453

52. Wichelhaus A (1999) Die Entwicklung und klinische Anwendung superelastischer Bögen und Teilbögen in der Kieferorthopädie. Quintessenz, Berlin
53. Wichelhaus A (2017) A new elastic slot system and V-wire mechanics. Angle Orthod 87:774-781. https://doi.org/10.2319/ 121516-899

54. Wichelhaus A, Brauchli L, Ball J, Mertmann M (2010) Mechanical behavior and clinical application of nickel-titanium closed-coil springs under different stress levels and mechanical loading cycles. Am J Orthod Dentofacial Orthop 137:671-678. https://doi.org/10. 1016/j.ajodo.2008.06.029

55. Wichelhaus A, Sander FG (1995) Biomechanical testing of the new torque-segmented arch (TSA). Fortschr Kieferorthop 56:224-235. https://doi.org/10.1007/bf02168135 